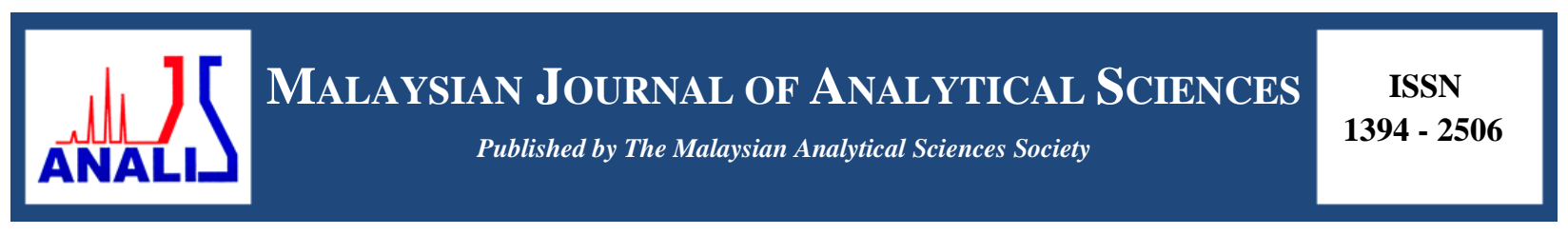

\title{
SPECTROSCOPIC CHARACTERIZATION OF COPPER(II)-BASED TETRAPEPTIDES
}

\author{
(Pencirian Spektroskopik Kuprum(II) Tetrapeptida) \\ Mohd. Basyaruddin Abdul Rahman ${ }^{1,2} *$, Sharifa Zaithun Begum ${ }^{1}$, Mohamed Ibrahim Mohamed Tahir ${ }^{2}$, \\ Haslina Ahmad ${ }^{1,2}$, Emilia Abdul Malek ${ }^{1,2}$ \\ ${ }^{1}$ Enzyme and Microbial Technology Research \\ ${ }^{2}$ Department of Chemistry, Faculty of Science \\ Universiti Putra Malaysia, 43400 UPM Serdang, Selangor, Malaysia \\ *Corresponding author: basya@upm.edu.my
}

Received: 17 August 2015; Accepted: 7 May 2016

\begin{abstract}
Five different histidine and aspartic acid based tetrapeptides were designed using LOMETS and PyMol. They were chemically synthesized following the solid phase Fmoc-peptide synthesis protocols and were analysed using the reverse-phase High Performance Liquid Chromatography (HPLC) $\mathrm{C}_{18}$ analytical column for the purity. The peptides were further analysed by Liquid Chromatography Mass Spectrometry (LCMS) to see if the desired peptides were synthesized systematically. Copper(II) acetate monohydrate was bound to the peptides and the best molar ratio for the binding of these metal salts to peptides was $2: 1$. These observations were monitored through several spectroscopic techniques. The first physical observations for the successful synthesis of metallopeptides were the colour change, the melting/decomposition points and the solubility of these metallopeptides. Due to the visible colour change of the peptides to metallopeptides, UV-Visible spectroscopy and UVFluorescence spectroscopy were used as a qualitative analysis tests and the results were in agreement with other researchers' data from similar researches.
\end{abstract}

Keywords: copper(II), histidine, aspartic acid, tetrapeptides, spectroscopic

\section{Abstrak}

Lima tetrapeptida berbeza yang mempunyai histidine dan asid aspartik direkabentuk oleh LOMETS dan PyMol. Tetrapeptida ini disintesis mengikut skim fasa pepejal peptida dan dianalisis menggunakan fasa sonsang Kromatografi Cecair Berprestasi Tinggi (HPLC) $\mathrm{C}_{18}$ turus analisis untuk mengetahui keaslian peptida. Kesemua peptida ini dianalisis mengunakan Kromatografi CecairSpektrometer Jisim (LC-MS) untuk mengkaji sintesis peptida secara sistematik. Kuprum(II) asetat monohidrat terikat kepada peptida dan nisbah mol yang terbaik untuk mengikat garam logam ini kepada peptida adalah 2:1. Cerapan ini telah dipantau melalui beberapa teknik spektroskopi. Pemerhatian fizikal pertama untuk logam peptida yang berjaya disintesis ialah perubahan warna, takat lebur/penguraian dan kebolehlarutan peptida logam ini. Oleh kerana perubahan warna yang nyata dalam dari peptida kepada logam peptida, spektroskopi Ultralembayung-tampak (UV-Vis) dan spektroskopi Ultralembayung-Pendafluor (UVFluorescence) digunakan sebagai ujian analisis kuantatif dan data yang diperolehi adalah setara dengan perolehan data bagi penyelidikan yang serupa.

Kata kunci: Kuprum(II), histidin, asid aspartik, tetrapeptida, spektroskopi 


\section{Introduction}

Metallopeptides that are easier and cheaper to synthesise when compared to metalloproteins have caught the attention of many researchers. Metallopeptides, synthesized from metal salt and peptides, are known as pseudoproteins. They imitate the applications of large proteins especially in the industrial field of catalysis as well as in biological applications [1]. Metallopeptides are hybrid structures that combine peptides and metal and in this project, the transition metal copper(II) was used, that has various roles when used as biological probes [2]. The purpose of inserting a metal, particularly a transition metal is to increase the stability of short chain peptides, to provide the active site for various organic catalytic reactions (by behaving like an enzyme), to act as an antimicrobial agent in peptides that have no antimicrobial properties, to improve the anticancer properties of peptides and also to proliferate normal cells, amongst others [3].

The industrial applications of metallopeptides are applicable only when there is an understanding on its synthesis, for instance, the stability of the copper(II)-tetrapeptides will be understood only when data is available on the structure and geometry of copper(II) binding to the peptide. After confirming the stability of the metallocomplex, they can be applied as a catalyst or in biological assays. In this project, copper(II) acetate was bound to tetrapeptides containing metal binding amino acids; histidine and aspartic acid. Sulphur containing amino acids, though they are also metal binding amino acids were not used as they can be hazardous when applied in biological applications. In this research, the confirmation of the binding of metal to side chain of a particular amino acid in the peptides through UV-Visible spectroscopy and UV-Fluorescence is discussed. A brief discussion on how these two spectroscopic techniques can help in predicting the geometry of the copper(II) peptides is outlined, whether they form square planar, tetrahedral or octahedral complexes.

\section{Materials and Methods}

Five peptides were designed (P1: (Fmoc)NH-HAAD, P2: (Fmoc)NH-HAFD, P3: (Fmoc)NH-HAVD, P4: NH ${ }_{2}-$ AGHD, P5: $\mathrm{NH}_{2}-\mathrm{PGHD}$ ), synthesized and purified. They were characterized by High Performance Liquid Chromatography-Ultraviolet detector (HPLC-UV) for its purity and Liquid Chromatography-Mass Spectroscopy (LC-MS) for confirmation of the formation of peptides by its molecular weight. Copper(II) acetate monohydrate was bound to these five peptides in a 2:1 mole ratio.

\section{Synthesis of metallopeptides}

Copper(II) acetate monohydrate $\left(\mathrm{Cu}\left(\mathrm{CH}_{3} \mathrm{COO}\right)_{2} \cdot \mathrm{H}_{2} \mathrm{O}(189 \mathrm{mg}, 2 \mathrm{~mol})\right.$ was dissolved in deionized water $(\sim 10 \mathrm{~mL}$ until all has dissolved) and heated in a water bath. In a separate test tube, the peptides P1-3 (300 mg) were dissolved in a mixture of deionized water and acetonitrile $(20 \mathrm{~mL}$ and $10 \mathrm{~mL}$ respectively). Except for P4 and P5, these peptides were dissolved in deionized water only $(20 \mathrm{~mL})$ as the other three peptides had an FMOC group (hydrophobic group). The metal salt solution (cooled to room temperature) was added dropwise into the peptide solution with constant stirring at $40-60{ }^{\circ} \mathrm{C}$. The resultant solution was stirred until the solution changed color and a precipitate was observed. After the precipitate was formed, the stirring was continued for another $1-2$ hours to ensure that the reaction was completed (No further observation). The precipitate was vacuum-filtered and washed with cold deionized water and dried with acetone [4]. The final product was analyzed and characterized biophysically using UV-Vis and UV-Fluorescence spectroscopy. The product was purified through crystallization.

\section{UV-Visible spectroscopic analysis of $\mathrm{Cu}(\mathrm{II})$-tetrapeptides and its parent peptides}

Peptides $(10 \mathrm{mM})$ and metallopeptides $(5-10 \mathrm{mM})$ were dissolved in $5 \mathrm{~mL}$ of water and $10 \mathrm{~mL}$ of $\mathrm{KH}_{2} \mathrm{PO}_{4}$ buffer [11.11 mM] separately and were placed into $1 \mathrm{~cm}$ path length rectangular quartz cuvettes. The UV-Vis wavelength range was set from $200-1000 \mathrm{~nm}$ with fast scanning speed. The average of three scan readings were taken and plotted.

\section{UV-Fluorescence spectroscopic analysis of $\mathrm{Cu}(\mathrm{II})$-tetrapeptides and its parent peptides}

Peptides $(10 \mathrm{mM})$ and metallopeptides $(5-10 \mathrm{mM})$ prepared for UV-Vis were used for UV- fluorescence as well. The samples were placed in a fluorescent cuvette. The scanning wavelength was set from $250-650 \mathrm{~nm}$. The excitation wavelength was set to $280 \mathrm{~nm}$. The slit width was $5 \mathrm{~nm}$ and the spectrum recorded was an average of three scans at fast speed. 


\section{Results and Discussion}

Five histidine and aspartic acid based tetrapeptides that were designed computationally had proven random secondary structure and were synthesized and analyzed by HPLC and LC-MS as shown in Table 1. Their physical observations and their $\%$ yields are also mentioned.

Table 1. Physical observations, solubility in water and \% yields of peptides

\begin{tabular}{llllc}
\hline No. & Peptides & Morphology of solid & Solubility in water & \% yield \\
\hline P1 & (Fmoc)NH-HAAD & White clumps & Hydrophilic & 74.0 \\
P2 & (Fmoc)NH-HAFD & Whitish-yellow powder & Hydrophobic & 74.2 \\
P3 & (Fmoc)NH-HAVD & White powder & Hydrophilic & 83.1 \\
P4 & $\mathrm{NH}_{2}$-AGHD & White powder & Hydrophilic & 69.9 \\
P5 & $\mathrm{NH}_{2}$-PGHD & White powder & Hydrophilic & 65.6 \\
\hline
\end{tabular}

Fmoc- Fluorenylmethyloxycarbonyl chloride

The purity of all these peptides was above $80 \%$ and they were not purified further. Copper(II) acetate-tetrapeptides (\% yields: $50-65 \%$ ) were analyzed by UV-Visible and UV-Fluorescence spectroscopy and the results are discussed in the sections below.

\section{UV-Visible spectral analysis}

One of the distinctive features of successful binding is the colour of the metallopeptide (refer to Figure 1). Colour is always associated with d-d transitions, ligand-metal charge transfer (LMCT) and metal-ligand charge transfer (MLCT). This analysis points out where and to what intensity these bands appear and are shown in Table 2.

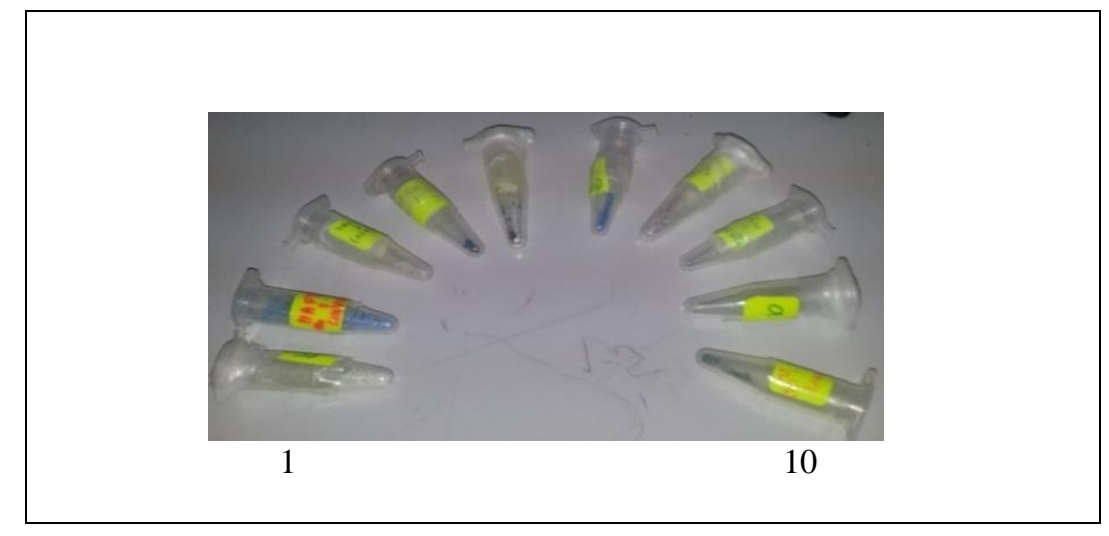

Figure 1. Copper(II) based tetrapeptides $(2,4,6,8$ and 10)

The results are in agreement with other reported data that $\mathrm{d}-\mathrm{d}$ transitions have absorptions at the said wavelength with molar absorptivity in the range of about $2-3 \mathrm{Lcm}^{-1} \mathrm{~mol}^{-1}[5]$ and the charge transfer bands (CT bands) for copper bound peptides normally have similar or lower molar absorptivity than that of d-d transition bands and appear in the range of $400-600 \mathrm{~nm}[6]$.

No charge transfer bands and only a weak d-d transition band were observed in MP5 probably due to the low concentration of metallopeptide. All the metal salts were expected to bind to the imidazole ring of histidine. This was observed in both the UV-Vis and UV-Fluorescence spectra. According to Boka et al., copper and zinc binds to 
the nitrogen $(\mathrm{C}=\mathrm{N})$ in the imidazole ring of histidine in the range of $250-300 \mathrm{~nm}$ giving rise to a strong sharp peak with high absorbance. However, it was also mentioned that copper also binds to the carboxylate side chain of aspartic acid and henceforth, the values are shifted further right (higher wavelength) due to the acidic nature of the metallopeptides [7], as observed in this study.

Table 2. d-d transition, LMCT and MLCT transitions of metallopeptides

\begin{tabular}{lcl}
\hline Metallopeptides $^{\mathbf{a}}$ & $\begin{array}{c}\text { Wavelength/nm } \\
\left(\mathbf{l o g} \mathbf{~} / \mathbf{~ L c m}^{-1} \mathbf{m o l}^{\mathbf{1}}\right)\end{array}$ & Assignment \\
\hline MP1 (Cu-P1-Cu) & $714(2.04)$ & d-d transition \\
& $458(1.98)$ & charge transfer \\
& $239(3.84)$ & bound to histidine \\
& $708(1.60)$ & d-d transition \\
MP2 (Cu-P2-Cu) & $530(1.72)$ & charge transfer \\
& $268(3.74)$ & bound to histidine \\
& $737(2.17)$ & d-d transition \\
MP3 (Cu-P3-Cu) & $648(2.23)$ & charge transfer \\
& $270(3.85)$ & bound to histidine \\
& $747(2.31)$ & d-d transition \\
& $518(1.25)$ & charge transfer \\
MP4 (Cu-P4-Cu) & $307(2.60)$ & bound to histidine \\
& $749(1.16)$ & d-d transition \\
& - & no charge transfer \\
MP5 (Cu-P5-Cu) & $264(1.93)$ & bound to histidine \\
\hline
\end{tabular}

\section{UV-Fluorescence spectral analysis}

UV-Fluorescence measures the intensity of light emitted during the relaxation process when a particular substance absorbs UV radiation. These substances are termed as chromophores. The imidazole ring, - $\mathrm{CONH}, \mathrm{COOH}$, and cyclic compounds are important chromophores in peptides. The shift in the wavelength and intensity of fluorescence emitted by these chromophores can be due to the presence of metal and other chromophores that are added into the system [8]. For instance, the presence of copper(II) binding to the nitrogen in the imidazole ring of His or to the $\mathrm{COOH}$ of the Asp resulted in quenching due to the formation of new bonds or electrostatic forces of attraction. Similarly, when copper(II) acetate was used to bind to peptides, the presence of acetate, a chromophore, could affect the peptide system. Either, an extra band was observed further down the wavelength or the intensity of the existing band increased [9], as observed in Figure 2.

In most cases, addition of any metal into peptide or protein results in the quenching of its parent peptide as observed in the range of $600-650 \mathrm{~nm}$ [10]. Just like the UV-vis spectra, a strong signal was observed in the range of $285-$ $340 \mathrm{~nm}$ (Figure 2). This was due to the presence of the imidazole ring of histidine [7]. In some of the metallopeptides, quenching was observed in this range. For the case of P4 and P5, the absence of Fmoc group at the $\mathrm{N}$-terminal made them unstable and hence such emittance bands were observed. As for the copper(II) complexes of these two peptides (Figure 3), due to the positions of histidine and aspartic acid side by side, and the free $\mathrm{N}$-terminal as a possible candidate for binding of one of the copper(II) ions also led to different results compared to MP1-3. 


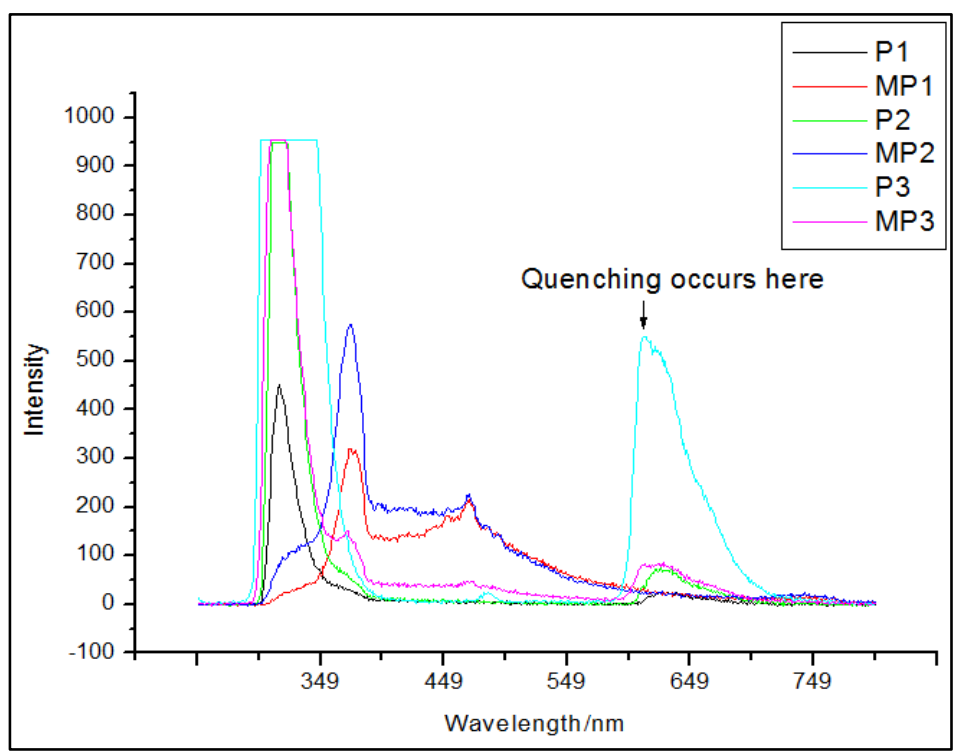

Figure 2. UV-Fluorescence spectra of P1-P3 and its copper(II) complexes

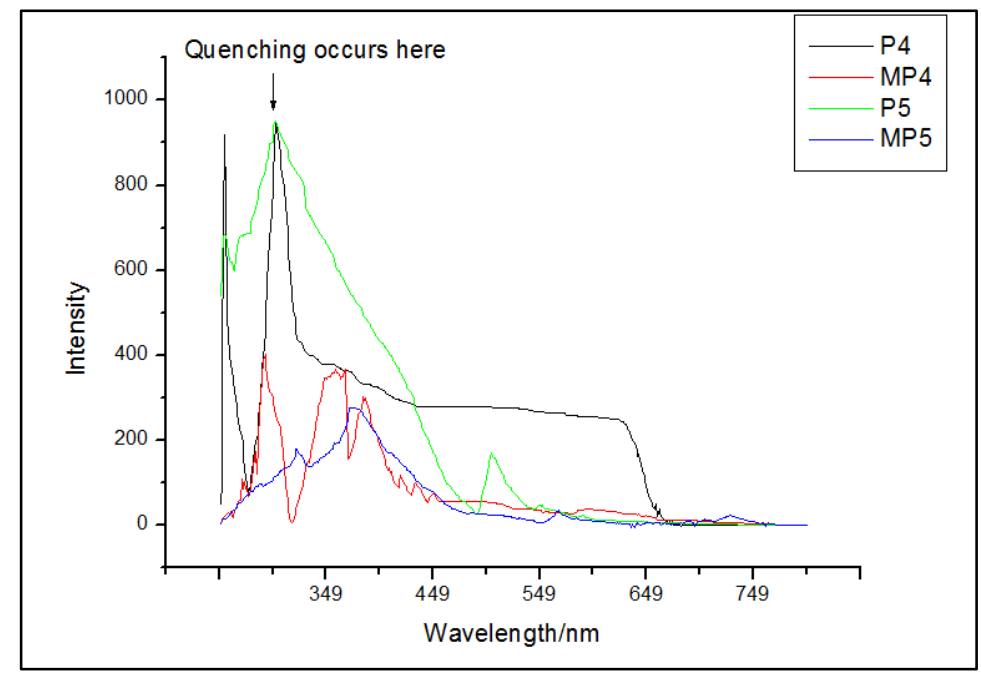

Figure 3. UV-Fluorescence spectra of P4, P5 and its copper(II) complexes

\section{Conclusion}

Based on the data reported in this work, it can be concluded that copper(II) acetate bound to the imidazole ring of histidine and at carboxylate of aspartic acid (one copper(II) at each amino acid) for all the peptides. The UVFluorescence shows the existence of the acetate $\left(\mathrm{CH}_{3} \mathrm{COO}\right)$ ion in the complex. From the color of copper-peptides (blue), it was also concluded that water was bound to the complex.. Hence, for each copper(II) complex, the geometry is predicted to be a square planar or tetrahedral. To confirm the structure and the geometry, single crystal X-ray diffraction needs to be carried out but suitable crystals have not yet been obtained. 


\section{Acknowledgement}

We gratefully acknowledge the Fundamental Grant Research Scheme (FGRS 5524292) entitled "Rational Design of Peptide Chiral Catalyst Based on Aldo-Ketoreductase for asymmetric Aldol reaction", the Faculty of Science, UPM and Malaysian Genome Institute for providing laboratory services and facilities.

\section{References}

1. Ming, L. J. (2010). Metallopeptides from drug discovery to catalysis. Journal of Chinese Chemical Society, 57: $285-299$.

2. Ball, Z. T. and Zaykov, A. N. (2011). A general synthesis of dirhodium metallopeptides as MDM2 ligands. Chemical Communications, 47: 10927 - 10929.

3. Tay, W. M (2010). Metallopeptides as model systems for the study of $\mathrm{Cu}(\mathrm{II})$-dependent oxidation chemistry, Thesis University of South Florida.

4. Sambasivan, R. and Ball, Z. T. (2010). Metallopeptides for asymmetric dirhodium catalysis. Journal of the American Chemical Society. 132: 9289 - 9295.

5. Karavelas, T., Mylonas, M., Malandrinos, G., Plakatouras, J. C., Hadjiliadis, N., Mlynarz, P. and Kozlowski, H. (2005). Coordination properties of $\mathrm{Cu}(\mathrm{II})$ and $\mathrm{Ni}(\mathrm{II})$ ions towards the C-terminal peptide fragment -ELAKHAof histone H2B. Journal of Inorganic Biochemistry. 99(2): 606 - 615.

6. Neupane, K. P, Aldous, A. R. and Kritzer, J. A. (2013). Macrocyclization of the ATCUN motif controls metal binding and catalysis. Inorganic Chemistry. 52(5): 2729 - 2735.

7. Boka, B., Myari, A., Sovago, I. and Hadjiliadis, N. (2004). Copper(II) and zinc(II) complexes of the peptides Ac-HisValHis- $\mathrm{NH}_{2}$ and Ac-HisValGlyAsp- $\mathrm{NH}_{2}$ related to the active site of the enzyme CuZnSOD. Journal of Inorganic Biochemistry. 98(1): 113 - 122.

8. Penner, M. H. (2010). Ultraviolet, visible and fluorescence spectroscopy. In Food Analysis, $4^{\text {th }}$ Ed., Suzanne Nielsen, Ed. Springer.

9. Goulding, A.M. (2010). Biochemical applications of DsRed-Monomer utilizing fluorescence and metal-binding affinity. Unpublished doctoral dissertation, Purdue University, Indianapolis, Indiana.

10. Deo, S.K., Rahimi, Y., Goulding, A., Shrestha, S., Mirpuri, S. (2008). Mechanism of copper induced fluorescence quenching of red fluorescent protein, DsRed. Biochemical and Biophysicsal Research Communication. 370(1): $57-61$. 